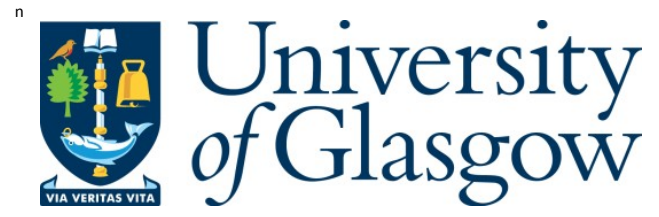

Dow, J. A . T., and Davies, S. A . (2015) W hat is an epitheliome, anyway? Insect Biochemistry and Molecular Biology, 67, p. 1.

There may be differences between this version and the published version. $Y$ ou are advised to consult the publisher's version if you wish to cite from it.

http://eprints.gla.ac.uk/114874/

Deposited on: 17 February 2016

Enlighten - R esearch publications by members of the U niversity of Glasgow http://eprints.gla.ac.uk 


\section{What is an epitheliome, anyway?}

Insects are extraordinarily successful class of life, with as many species (>10M) as all other classes of living organism combined. How are they so successful in exploiting such a diverse range of ecological niches? Any insect biologist could make a convincing case for the importance of any behaviour, organ or physiological process; after all, everything we see in insects today is the product of $500 \mathrm{My}$ of evolutionary refinement. Indubitably though, insects both on land and in water must maintain an internal milieu that is closely regulated homeostatically, and distinct from the outside world. Epithelia, or sheets of cells, are tasked with keeping both the insect separate from the outside world, and with separating different domains within the insect. An epitheliome is thus a conceptual grouping of all of the processes, expressed genes or proteins that make up a functional epithelium, and distinguish them from other epithelia.

In this volume, we take the integrative approach implicit in our definition of the epitheliome to ask how some of the classical insect epithelia (for example integument, alimentary canal, renal tubules) contribute to the success of Class Insecta. Implicit in this, of course is an applied benefit - that pharmacological disruption of insect epithelia could provide new, more selective tools for insect control. There is already a precedent for such an approach, of course: Bacillus thuringiensis demonstrates the catastrophic impact of disruption of gut epithelial integrity.

Another theme through these, and some other recent articles, is that epithelia are charged with multiple roles that go beyond what we learn in the textbooks. We can no longer say, for example, that the midgut digests and absorbs food, because it is clear that such tissues have multiple regions and cell types. They also perform multiple roles; for example in innate immunity or as metabolic tissues in their own right. It is thus timely to look at epithelia with fresh eyes.

Julian A. T. Dow \& Shireen A. Davies

University of Glasgow. 